\title{
Analisis Kesalahan Siswa dalam Menyelesaikan Masalah Aljabar Siswa Kelas VII SMP Negeri 6 Kota Sorong
}

\author{
Zakiyah Anwar \\ Prodi Pendidikan Matematika, Fakultas KIP, Universitas Muhammadiyah Sorong, \\ Jl. Pendidikan km.8,Kota Sorong,Papua Barat, Indonesia
}

Diterima:10 Oktober 2016. Disetujui:20 November 2016. Dipublikasikan:1 Desember 2016

\begin{abstract}
ABSTRAK
Penelitian ini adalah penelitian deskriptif yang bertujuan untuk mengetahui persentase kesalahankesalahan yang dilakukan siswa dalam menyelesaikan masalah aljabar. Populasi dalam penelitian ini adalah siswa kelas VII, SMP Negeri 6 Kota Sorong. Sampel yang diambil dalam penelitian ini sebanyak 35 orang dengan cara Cluster Proportional Random Sampling. Data dikumpulkan dengan cara pemberian tes. Teknik analisa data dalam penelitian ini menggunakan analisis deskriptif. Analisis ini digunakan untuk mengetahui persentase kesalahan yang dilakukan siswa dalam menyelesaikan masalah aljabar untuk tiap jenis kesalahan. Dari hasil penelitian diperoleh data sebagai berikut persentase tiap jenis kesalahan yang dilakukan oleh siswa dalam menyelesaikan masalah aljabar adalah kesalahan konsep sebesar 54, 73\% dikategorikan dalam kategori rendah, kesalahan fakta sebesar 5,71\% dikategorikan dalam kategori sangat rendah, kesalahan prinsip sebesar 53,85\% dikategorikan dalam katergori rendah, kesalahan keterampilan sebesar 82,86\% dikategorikan dalam kategori tinggi.
\end{abstract}

Keywords: Analisis; Kesalahan;Masalah Aljabar

\section{Pendahuluan}

Dalam perkembangan Ilmu Pengetahuan dan Teknologi (IPTEK), matematika memegang peranan yang sangat penting, karena matematika selain salah satu pengetahuan dasar yang diperlukan oleh siswa untuk keberhasilan belajarnya dalam menempuh pendidikan yang lebih tinggi, matematika juga diperlukan oleh semua orang dalam kehiduan seharihari. Matematika juga merupakan salah atu sarana untuk mengembangkan kemampuan berpikir logis, sistematis dan kritis.

Kenyataan bahwa siswa kurang didorong untuk mengembangkan kemampuan berpikir. Proses pembelajaran matematika di dalam kelas diarahkan kepada kemampuan siswa untuk menghafal informasi, siswa dipaksa untuk mengingat dan menimbun berbagai informasi yang diingatnya itu untuk menghubungkan dengan kehidupan sehari-hari.

Mata pelajaran matematika tidak dapat mengembangkan kemampuan siswa untuk berpikir kritis dan sistematis, karena strategi pembelajaran berpikir tidak digunakan secara baik dalam setiap proses pembelajaran di dalam kelas.

Berbicara tentang pembelajaran matematika di sekolah tidak akan terlepas dari masalah-masalah yang terdapat di dalam pembelajaran tersebut. Para pendidik matematika pun baik di sekolah dasar maupun di sekolah menengah menyadari bahwa konsep, fakta, prinsip dan keterampilan dalam matematika sukar dikuasai oleh siswa, khususnya yang berhubungan dengan bidang studi matematika.

Kecakapan atau kemahiran matematika yang diharapkan dapat tercapai dalam belajar matematika mulai dari SD/MI sampai SMA/ MA, adalah sebagai berikut:

(1)Menunjukkan pemahaman konsep matematika yang dipelajari. Menjelaskan keterkaitan antara konsep dan mengaplikasikan konsep atau algoritma, secara luwes, akurat, efisien, dan tepat, dalam pemecahan masalah.(2)Memiliki kemampuan mengkomunikasikan gagasan dengan simbol. tabel. Grafik atau diagram untuk memperjelas keadaan atau masalah.(3) 


\section{Jurnal Noken 2(1) 10-13 2016}

Menggunakan penalaran pada pola, sifat atau melakukan manipulasi matematika dalam membuat generalisasi, menyusun bukti, atau menjelaskan gagasan dan pernyataan matematika.(4)Menunjukkan kemampuan strategi dalam membuat (merumuskan), menafsirkan, dan menyelesaikan model matematika dalam pemecahan masalah(5)Memiliki sikap menghargai kegunaan matematika dalam kehidupan.

Menyadari pentingnya peranan dan tujuan pembelajaran matematika di atas, maka sangatlah diharapkan agar siswa menguasai pelajaran matematika sesuai dengan tuntutan kurikulum. Namun suatu kenyataan yang tak dapat dipungkiri sampai saat ini bahwa penguasaan siswa terhadap matematika relatif rendah. Hal ini disebabkan kurangnya kemampuan konsep dan prinsip mengidentifikasi data, melihat fakta dan mengoperasikan soal-soal matematika. Salah satu penyebab kesulitan dalam menyelesaikan soal-soal matematika adalah kurangnya penguasaan materi prasyarat sebelum melangkah ke materi selanjutnya. Untuk mengetahui kesulitan siswa maka perlu diadakan penelusuran kesalahan yang dilakukan siswa.

Peningkatan mutu pendidikan dapat dilihat dari prestasi yang dicapai siswa, sedangkan berhasil tidaknya siswa mencapai hasil belajar matematika dapat dilihat dari kemampuan siswa menyelesaikan soal matematika dengan benar. Namun dalam menyelesaikan soal matematika seringkali siswa membuat kesalahan.

\section{Metode Penelitian}

\section{A. Jenis Penelitian}

Penelitian ini merupakan suatu penelitian deskriptif. Penelitian ini bertujuan untuk mendeskripsikan jenis jenis kesalahan dan pada bagian mana siswa banyak melakukan kesalahan dalam menyelesaikan masalah aljabar

B. Variabel Penelitian

Variabel yang diteliti dalam penelitian ini adalah variabel tunggal yaitu kesalahan siswa dalam menyelesaikan masalah aljabar meliputi kesalahan konsep, melihat fakta. menggunakan keterampilan dan prinsip.

\section{Defenisi Operasional Variabel}

Kesalahan siswa yang dimaksud dalam penelitian ini adalah kekeliruan yang dibuat oleh siswa dalam menyelesaikan masalah aljabar. Adapun indikator kesalahan adalah :

$\mathrm{K} 1=$ Kesalahan konsep

Kesalahan konsep adalah ketidakmampuan siswa dalam memahami dan mengenali sifat yang sama yang terdapat pada berbagi objek atau peristiwa berdasarkan defenisi dari aljabar.

$\mathrm{K} 2=$ Kesalahan fakta,
Kesalahan dalam melihat fakta adalah ketidakmampuan dalam mengenali dan membedakan berbagai simbol yang digunakan untuk mencari penyelesaian soal aljabar K3 = Kesalahan prinsip

Kesalahan dalam menggunakan prinsip-prinsip matematika adalah ketidakmampuan siswa dalam menggunakan aturan-aturan dan memahami berbagai pernyataan yang dapat memberi petunjuk bagaimana harus bertindak dan mampu menggunakannya pada situasi tertentu dalam mencari penyelesaian soal-soal matematika.

K4= Kesalahan keterampilan

Kesalahan dalam menggunakan keterampilan matematika disini adalah ketidakmampuan siswa menggunakan berbagai operasi dan prosedur dalam mencari penyelesaian soal aljabar

D. Populasi dan Sampel

Populasi

Populasi dalam penelitian ini adalah siswa kelas VII, SMP Negeri 6 Kota Sorong

2. Sampel

Jumlah sampel yang diambil dalam penelitian ini sebanyak 35 orang dengan cara Cluster Proportional Random Sampling. Adapun langkah-langkah pengambilan sampel adalah sebagai berikut:

Langkah Pertama:

Mengidentifikasi semua kelas VII SMP Negeri 6 Kota Sorong yang tersebar dalam 4 kelas.

Langkah kedua:

Membuat kerangka sampling (sampel) pada masingmasing kelas dengan siswa sebagai unit sampling.

Cluster terhadap 6 kelas yang ada dikelas VII kemudian dari tiap cluster (kelompok) diambil secara proporsional E. Instrumen Penelitian

Mengetahui kesalahan yang mungkin dilakukan oleh siswa pada saat menyelesaikan soal-soal matematika yang juga secara langsung dapat diketahui kemampuan dan penguasaan siswa terhadap materi aljabar. Maka dalam penelitian ini instrumen yang dibuat berbentuk tes essay dengan memperhatikan ruang lingkup pelajaran Matematika berdasarkan kurikulum berbasis kompetensi. Serta terlebih dahulu berkonsultasi dengan dosen pembimbing dan telah divalidasi oleh dua orang dosen matematika.

F. Teknik Pengumpulan Data

Adapun teknik pengumpulan data adalah dengan memberikan tes essay kepada siswa dalam tempo waktu 90 menit, dimana tes tersebut digunakan untuk mengetahui kesalahan-kesalahan siswa dalam menyelesaikan soa-soal aljabar.

\section{G. Teknik Analisis Data}

Jumlah kesalahan yang dilakukan oleh siswa dalam menyelesaikan soal-soal aljabar dianalisis dengan menggunakan analisis deskriptif. Analisis ini digunakan untuk mendeskripsikan karakteristik distribusi kesalahan 


\section{Jurnal Noken 2(1) 10-13 2016}

yang dilakukan oleh siswa, dan untuk mengetahui presentase kesalahan yang dilakukan oleh siswa dalam menyelesaikan masalah aljabar berdasarkan jenisnya, maka digunakan skor standar yang sifatnya absolut. Skor standar yang digunakan adalah yang di tetapkan Departemen Pendidikan dan Kebudayaan sebagai berikut:

Tabel 3.2. Teknik Kategori Standar yang ditetapkan oleh Departemen Pendidikan Nasional.

\begin{tabular}{lc}
\hline Persentase & Kategori tingkat kesalahan \\
\hline $85 \%-100 \%$ & Sangat tinggi \\
$65 \%-84 \%$ & Tinggi \\
$55 \%-64 \%$ & Sedang \\
$35 \%-54 \%$ & Rendah \\
$0 \%-34 \%$ & Sangat Rendah \\
\hline
\end{tabular}

Data hasil penelitian diperiksa tentang jenis kesalahan yang dilakukan siswa dalam menyelesaikan masalah matematika khususnya masalah aljabar. Persentase masing-masing kesalahan dapat diperoleh dengan cara menggunakan rumus proporsi kesalahan

$$
\text { yaitu: } K i=\frac{T i}{T} X 100 \%
$$

$\mathrm{Ki}=$ Persentase tiap jenis kesalahan

$$
T_{i}=\text { Banyaknya kesalahan untuk tiap jenis }
$$
kesalahan

$\mathrm{T}=$ Total kesalahan yang mungkin terjadi untuk tiap jenis kesalahan

\section{Hasil Penelitian}

Hasil penelitian dan pengolahan data yang disajikan dalam penelitian ini adalah dengan menggunakan statistika deskriptif. Analisis deskriptif ini meliputi persentase siswa dari tiap-tiap jenis kesalahan yang dilakukan dalam menyelesaikan masalah aljabar pada siswa kelas VII SMP Negeri 6 Kota Sorong. Hasil pengolahan data ditampilkan pada tabel berikut:

Tabel 4.1 Persentase kesalahan yang dilakukan oleh siswa kelas VII SMP Negeri 6 Kota Sorong dilihat dari empat jenis kesalahan.

\begin{tabular}{lllll}
\hline N & jenis kesalahan & $\begin{array}{l}\text { Jumlah } \\
\text { kesalahan }\end{array}$ & $\begin{array}{l}\text { Kotal } \\
\text { Yang } \\
\text { Mungkin } \\
\text { Terjadi }\end{array}$ & $\begin{array}{l}\text { Persentase } \\
\text { Kesalahan }\end{array}$ \\
\hline 1. & kesalahan konsep (k1) & 249 & 455 & 54,73 \\
2. & kesalahan fakta (k2) & 6 & 105 & 5,71 \\
3. & $\begin{array}{l}\text { kesalahan prinsip(k3) } \\
\text { kesalahan }\end{array}$ & 245 & 455 & 53,85 \\
4. & keterampilan(k4) & 290 & 350 & 82,86 \\
\hline
\end{tabular}

Dari Tabel 4.1 di atas diketahui bahwa persentase tiap jenis kesalahan yang dilakukan oleh siswa dalam menyelesaikan masalah aljabar adalah kesalahan konsep sebesar 54, 73\% dikategorikan rendah, kesalahan fakta sebesar $5,71 \%$ dikategorikan sangat rendah, kesalahan prinsip sebesar $53,85 \%$ dikategorikan rendah, sebesar $82,86 \%$ dikategorikan tinggi.

\section{Pembahasan Hasil Penelitian}

Seperti yang telah dikemukakan bahwa tujuan penelitian adalah untuk mengetahui persentase kesalahan yang dilakukan siswa untuk tiap jenis kesalahan dalam menyelesaikan masalah aljabar.

Berdasarkan hasil analisi deskriptif dapat dikemukakan bahwa Kesalahan-kesalahan siswa dalam menyelesaikan masalah aljabar adalah sebagi berikut:

1. Kesalahan konsep

Banyaknya kesalahan konsep yang dilakukan oleh siswa adalah 249 sedangkan total kesalahan yang mungkin terjadi adalah 455 sehingga persentase kesalahan adalah $54,73 \%$. Kesalahan konsep terjadi karena pada umumnya siswa tidak mampu menjawab soal sampai tuntas, dan masih banyak soal yang sama sekali tidak dikerjakan sehingga dapat disimpulkan bahwa responden belum memahami konsep yang benar.

2. Kesalahan melihat fakta

Banyaknya kesalahan fakta yang dilakukan oleh siswa adalah 6 sedangkan total kesalahan yang mungkin terjadi adalah 105 sehingga persentase kesalahan adalah $5,71 \%$ dikategorikan sangat rendah. Kesalahan fakta yang dilakukan oleh siswa pada umumnya terjadi karena ketidakmampuan siswa menuliskan menetapkan lambang dan notasi dengan baik dan benar.

3. Kesalahan prinsip

Banyaknya kesalahan prinsip yang dilakukan oleh siswa adalah 245 sedangkan total kesalahan yang mungkin terjadi adalah 455 sehingga persentase kesalahan prinsip $53,85 \%$. Kesalahan prinsip yang dilakukan oleh siswa pada umumnya terjadi karena siswa tidak mampu menggunakan operasi-operasi bilangan. Kesalahan dalam perhitungan dan memanipulasi operasi dasar aljabar yang terdiri dari penjumlahan, pengurangan, pembagian dan perkalian yang dilakukan oleh siswa.

4. Kesalahan keterampilan

Banyaknya kesalahan konsep yang dilakukan oleh siswa adalah 290 sedangkan total kesalahan yang mungkin terjadi adalah 350 sehingga persentase kesalahan $82,86 \%$ dikategorikan tinggi. Kesalahan keterampilan terjadi karena pada umumnya siswa tidak dapat menyelesaikan soal aljabar sesuai prosedur. Kesalahn tersebut terjadi sebagai kaibat dari kesalahan konsep dan kesalahan prinsip yang dilakukan siswa sehingga langkah-langkah selanjutnya menjadi salah selain itu urutan langkah-langkah penyelesaian soal juga tidak sistematis berdasarkan jawaban akhir yang diberikan masih dalam bentuk terbuka artinya masih ada langkah penyelesaian selanjutnya yang tidak dituliskan oleh siswa.

\section{Kesimpulan}

\section{Analisis kesalahan dalam menyelesaikan soal ....}


Banyaknya kesalahan konsep yang dilakukan oleh siswa kelas VII SMP Negeri 6 Kota Sorong dalam menyelesaikan masalah aljabar sebesar 54,73\%, Persentase kesalahan konsep ini tergolong rendah.

Banyaknya kesalahan fakta yang dilakukan oleh siswa kelas VII SMP Negeri 6 Kota Sorong dalam menyelesaikan masalah aljabar sebesar $5,71 \%$ Persentase kesalahan fakta ini tergolong sangat rendah.

Banyaknya kesalahan prinsip yang dilakukan oleh siswa kelas VII SMP Negeri 6 Kota Sorong dalam menyelesaikan masalah aljabar sebesar 53,85\%. Persentase kesalahan prinsip ini tergolong rendah.

Banyaknya kesalahan keterampilan yang dilakukan oleh siswa kelas VII SMP Negeri 6 Kota Sorong dalam menyelesaikan masalah aljabar sebesar $82,86 \%$. Persentase kesalahan keterampilan ini tergolong tinggi.

Daftar Pustaka

Bani, Nurwati, 2005. Implementasi Assesment Portofolio Untuk Meningkatkan Kualitas Hasil Belajar Matematika Siswa Kelas 1 Tekstil SMKN 2 Somba Opu Sungguhminasa. Skripsi. Makassar: Tidak diterbitkan

Depertemen Pendidikan Dan Kebudayaan. 1993. Evaluasi dan penelitian. Jakarta: Proyek Mutu Guru. Dirjen Pendidikan

Pusat Pembinaan dan Pengembangan Bahasa, 1994. Kamus Besar Bahasa Indonesia. Jakarta. Balai Pustaka

Rohani, 2000. Profil Kesalahan Siswa dalam Menyelesaikan Masalah Matematika Persamaan dan Pertidaksamaan Kuadrat . Skripsi. Makassar. Tidak diterbitkan

Slameto, 2003. Belajar dan Faktor-Faktor yang Mempengaruhinya. Edisi Revisi Jakarta. Rineka Cipta

Sudjana, Nana, 2004. Penelitian dan Penilaian Pendidikan. Bandung; Sinar Baru 2005. Pengembangan Program Pengajaran Matematika. Depertemen Pendidikan Nasional Universitas Negeri Makassar Matematika Fakultas Matematika dan Ilmu Pengetahuan Alam

Wahyudin Djumanta, 2004. Matematika Untuk SMP Kelas VII Semester 1. Bandung; Grafindo

Widyastuti, 2004. Identifikasi Kesalahan Menyelesaikan Sola Turunan Fungsi Trigonometri Pada Siswa Kleas XI IPA SMA Negari 3 Makassar. Skripsi. Makassar; Tidak diterbitkan 